\title{
Southern elephant seal vagrants in Ecuador: a symptom of La Niña events?
}

\author{
Diego Páez-Rosas ${ }^{1,2}$, Marjorie Riofrío-Lazo ${ }^{1,3}$, Jorge Ortega ${ }^{4}$, Juan de Dios Morales ${ }^{5}$, Raúl Carvajal ${ }^{6}$ \\ and Juan José Alava ${ }^{7,8^{*}}$ iD
}

\begin{abstract}
Background: Extralimital observations of pinnipeds are important to understand the effects of changing climates on our oceans and the distribution of these species. The southern elephant seal (Mirounga leonina) is a known vagrant species that moves over long distances. We report three new records of $M$. leonina in interior freshwater tributaries of the Guayas River Estuary Basin (Gulf of Guayaquil) and northern coast of Ecuador between October 2017 and January 2018 during a cold episode of La Nina event in the southeastern Pacific.
\end{abstract}

Results: The elephant seals were identified according to their large size ( $5 \mathrm{~m}$ for adult and 2-3 $\mathrm{m}$ for juveniles/ subadults), the head to neck size ratio, and the size and external morphology of the proboscis, which was used as a key trait to differentiate M. leonina from the Northern elephant seal (M. angustirostris). The observations of M. leonina in Ecuador highlight an extreme movement covering an assumed total distance of approximately $8000 \mathrm{~km}$ from the circumpolar region. The cold event "La Niña" with sea surface temperature anomalies ranging $-1.5^{\circ} \mathrm{C}$ to $-0.5^{\circ} \mathrm{C}$ in October 2017 likely triggered the extralimital movements of these animals.

Conclusion: Recurring observations of M. leonina in the Guayaquil Gulf suggest the importance of this highly productive region and tropical estuarine-riverine habitats as temporary haulout sites for resting. These new findings indicate that vagrant individuals influenced by oceanographic events and eco-physiological processes are reaching this region more frequently than previously thought.

Keywords: Mirounga leonina, Southern elephant seal, Extralimital movement, Gulf of Guayaquil, Ecuador, La Niña

\section{Background}

The southern elephant seal (Mirounga leonina) is the largest pinniped in the world and is not habitually found in tropical areas because of its circumpolar and sub-Antarctic distribution in the southern ocean (Le Boeuf and Laws 1994; Jefferson et al. 2015). Adult southern elephant seals present a marked sexual dimorphism due to their polygynous system (Le Boeuf 1974; Baldi et al. 1996). Adult males can be much larger than females and have a long proboscis; males reach a length of up to 5-6 $\mathrm{m}$ and a maximum weight of $4000 \mathrm{~kg}$, while females measure $\sim 3 \mathrm{~m}$ and weigh 400-900 kg (Le Boeuf and Laws 1994; Modig 1996; Jefferson et al. 2015). The global southern elephant seal

\footnotetext{
* Correspondence: j.alava@oceans.ubc.ca

${ }^{7}$ Fundación Ecuatoriana para el Estudio de Mamíferos Marinos (FEMM), Guayaquil, Ecuador

${ }^{8}$ Institute for the Oceans and Fisheries, University of British Columbia,

Vancouver, BC, Canada

Full list of author information is available at the end of the article
}

population has been estimated at 700,000 individuals greater than one year of age, with an annual production of 189,000 pups (Le Boeuf and Laws 1994; Lewis and Campagna 2005; McMahon et al. 2005).

This species is widely distributed in the circumpolar and sub-Antarctic islands, where it is assembled in three population groups: South Georgia, Kerguelen and Macquarie (Deméré et al. 2003; McMahon et al. 2005). The South Georgia population group is comprised of the populations existing on the South American continent, including the Valdés Peninsula and Malvinas Islands (Slade et al. 1998; Hoelzel et al. 2001), as well as a small colony located in Ainsworth Bay, Magallanes Region (i.e. XII Region of Magallanes) and Chilean Antarctica (Vargas 2012). Breeding and moulting haulouts, as well as winter haulouts of southern elephant seals are also found at Marion Islands, South Africa (Kirkman et al. 2001; Kirkman et al. 2003; Kirkman et al. 2004). 
The life cycle of $M$. leonina has two terrestrial stages, including a stage dedicated to moulting (predominantly from December to February) and another for reproduction (September-October). This species has two ocean life stages, i.e. post-moulting and post-reproduction (Campagna et al. 1993; Le Boeuf and Laws 1994). During the non-breeding season, adult and sub-adult males tend to undertake large migrations over thousands of kilometers in the Antarctic Ocean for feeding, with some vagrant individuals observed beyond or outside of their normal range (Hindell and McMahon 2000; Fabiani et al. 2003; Lewis and Campagna 2005; Lewis et al. 2006; Campagna et al. 2006; Reisinger and Bester 2010; Jefferson et al. 2015).

Oceanographic-atmospheric events such as El Niño (i.e. ENSO events) and La Niña have severe impacts affecting the migration patterns and feeding trips of pinnipeds (Alava and Salazar 2006; Avila et al. 2015; Alava and Aurioles-Gamboa 2017; Elorriaga-Verplancken et al. 2016, Páez-Rosas et al. 2017; Quintana-Rizzo et al. 2017). These changes are generally associated with the availability of food due to the displacement of prey towards colder regions or deeper waters (Soto et al. 2004; Trites et al. 2007). For instance, La Niña is accompanied by a decrease in sea surface temperature (SST), producing changes in ocean circulation dynamics around the South American continent and eastern Tropical Pacific (Kessler 2006). This event can lead to anomalies in the distributional pattern of tropical species, or in the migration of species from relatively cold waters to warmer areas (Ballance et al. 2006).

The dispersal capacity of pinnipeds has contributed to the movement of several species (e.g., harbour seals, Phoca vitulina; hooded seal, Cystophora cristata; southern elephants seals, M. leonina, Juan Fernandez fur seal, Arctocephalus philippii; Galapagos fur seals; Arctocephalus galapagoensis; Guadalupe fur seals, Arctocephalus towsendi) hundreds or even thousands of kilometers away from their feeding or breeding areas (Johnson 1990; Reeves et al. 2002; Alava and Carvajal 2005; Avila et al. 2015; Alava and Aurioles-Gamboa 2017; Páez-Rosas et al. 2017; Quintana-Rizzo et al. 2017), with many sightings involving cases associated with vagrant adult individuals at sea and along coastal regions during their feeding trips. Southern elephant seal adults have been reported resting on the coasts of Brazil, Ecuador, Galapagos Islands, Chile, Panama, Peru, South Africa, Australia and New Zealand (Reeves et al. 2002; Magalhães et al. 2003; Vargas and Steinfurth 2004; Lewis and Campagna 2005; Alava and Carvajal 2005; Lewis et al. 2006; Sepúlveda et al. 2007; Acevedo et al. 2016; Mayorga et al. 2017; Stewart and Felix 2018). Of particular relevance here is the presence of southern elephant seals reported in 1998 and 2002 in the Gulf of Guayaquil, Ecuador (Alava and
Carvajal 2005), where the authors suspected both animals to be vagrant $M$. leonina and photos of the animals suggest this identification is reliable (Alava and Carvajal 2005; Jefferson et al. 2015).

In this work, we report apparently healthy M. leonina in the Guayas River Basin (Gulf of Guayaquil) and on Ecuador's north coast, and discuss the possible influence of La Niña event as a driving atmospheric-oceanographic force affecting the distribution and behavioral patterns of the species.

\section{Methods}

Four sightings of elephant seals in the Gulf of Guayaquil and on the coast of Ecuador between October 2017 and January 2018 are described here. The first record is located at the Babahoyo River sub-basin, which is one of the main tributaries of the Guayas River, in the Gulf of Guayaquil (Fig. 1). The Guayas River is formed at the confluence of the Babahoyo and Daule Rivers. The elephant seal was first sighted on 24 October 2017 in apparently healthy condition (i.e. signs of emaciation and external injuries were not observed) and hauling out on the riverbanks of the Milagro River $\left(2^{\circ} 6^{\prime} 33^{\prime \prime} \mathrm{S}, 79^{\circ}\right.$ $\left.41^{\prime} 10^{\prime \prime} \mathrm{W}\right)$, a small river located at the Yaguachi Municipality (Guayas Province) approximately $75 \mathrm{~km}$ from the outer estuary of the Guayaquil Gulf at the Ecuadorian Pacific (Fig. 1). The elephant seal was photographed (Fig. 2a), and monitored by the Wildlife Department (Ministry of Environment of Ecuador) for a period of 24 h. Subsequently, the Civil Defense and Firefighter departments arrived at the site to prevent harassment from the local people and allow the elephant seal to move from this river and enter the Babahoyo River.

Following this event, an elephant seal was spotted on 28 October 2017 and assumed to be the same individual due to the similar size and infrequent occurrence of this species in the region (Fig. 2b). The animal was swimming farther north of the Milagro River along the Arenal River (146'22" S, 79³9'58' W). The Arenal River is a small inland river from the Municipality of Baba (Los Ríos Province) flowing into the Babahoyo River, and located at approximately $105 \mathrm{~km}$ from the outer estuary of the Guayaquil Gulf. After these two sightings, the animal was no longer recorded in the region, suggesting that the elephant seal left the coast and continued with its feeding trip in the Pacific Ocean.

Succeeding these sightings, two other reports of elephant seals were made along the Ecuadorian coast. A second individual (Fig. 2c) was observed on 10 December 2017. This animal was spotted for about two hours hauling out around an inland freshwater flooded and mud-covered field and the riverbanks of a narrow creek at the Yaguachi Municipality, Guayas Province $\left(2^{\circ} 5^{\prime} 48.5^{\prime \prime} \mathrm{S}, 79^{\circ} 41^{\prime} 41.4^{\prime \prime} \mathrm{W}\right)$. The third animal was recorded in the northern coast of Ecuador at 


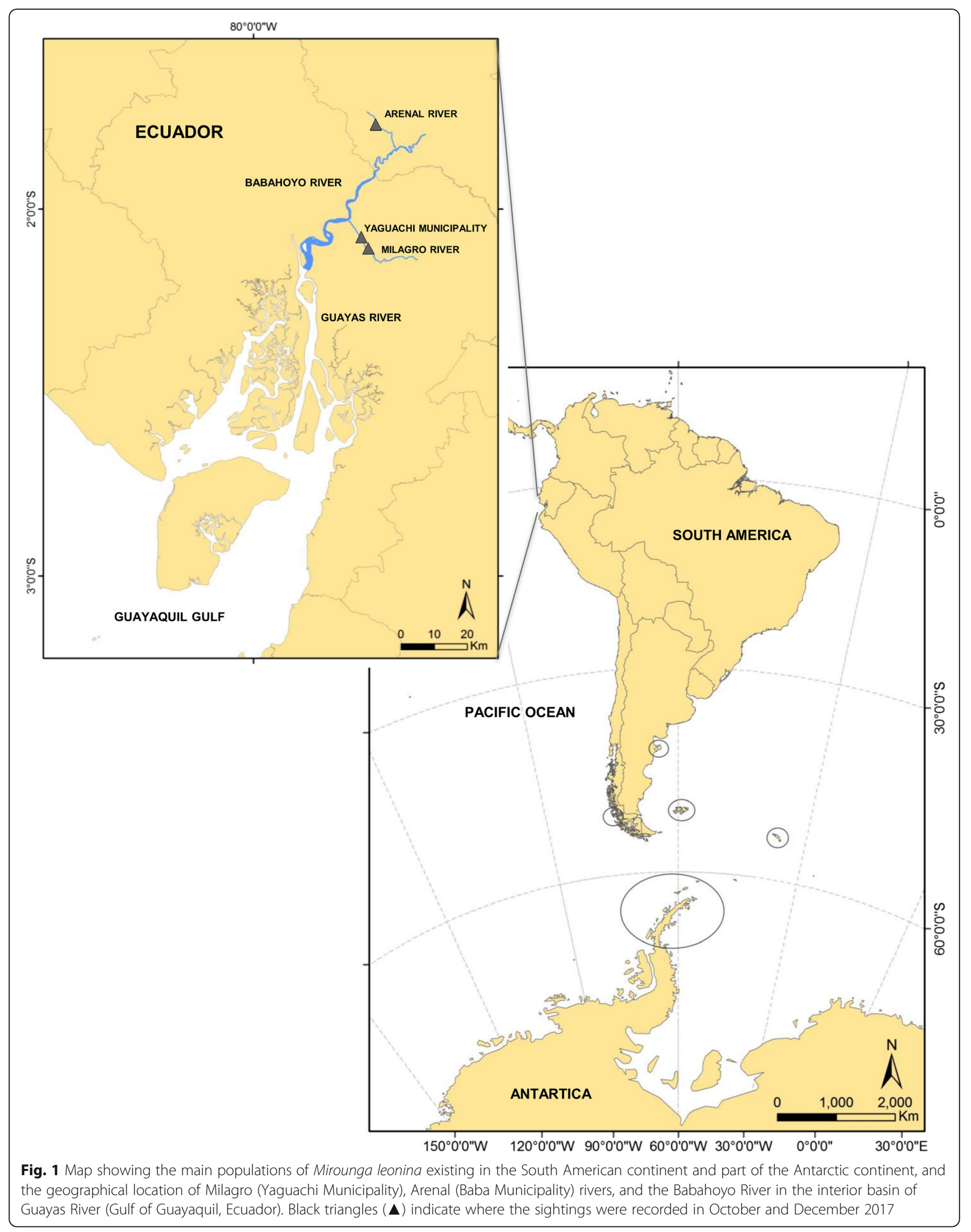




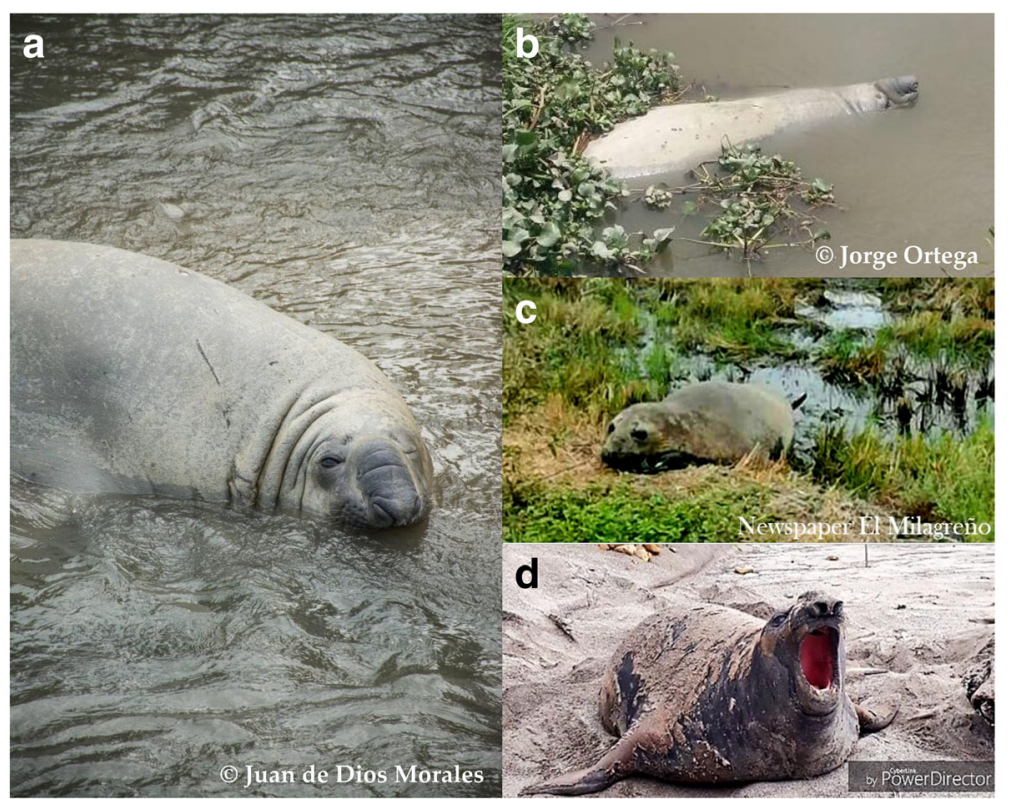

Fig. 2 Southern elephant seals (M. leonina) observed in the interior Guayas River Estuary Basin (a-c) and the Ecuadorian north coast (d) in 2017. The size of both the proboscis and body of this individual are diagnostic traits for an adult male of $M$. leonina. $\mathbf{a}, \mathbf{b}$ Photos of the adult male ( $5 \mathrm{~m}$ length) hauling out on the riverbanks of the Milagro and Arenal rivers. c Photo of the juvenile was observed in Yaguachi Municipality; the snout without a developed proboscis, as well as the size of this animal are attributes of a juvenile for this species (Photo credit: Newspaper El Milagreño). $\mathbf{d}$ Photo of subadult male with signs of moulting, observed resting on a beach of Tonsupa (Photo credit: Ministry of Environment of the Esmeraldas Province)

Tonsupa, Esmeraldas Province (053'12" S, 7948'46" W), on 24 January 2018. This individual was resting on the beach, where it was exhibiting signs of moulting (Fig. 2d). Apparently, the same animal was spotted ten days later further south in Atacames, Esmeraldas Province $\left(0^{\circ} 52^{\prime} \mathrm{N}\right.$, $79^{\circ} 50^{\prime} \mathrm{W}$ ) on 3 February 2018 by personnel from the Ministry of Environment of Ecuador, who monitored the animal and corroborated that was the same individual observed in Tonsupa (R. Carvajal, pers. comm., 5 February 2018).

The taxonomic identification of the sighted animals was based on the external morphological attributes, including body size and coloration, ratio of neck to head size, and the shape and size of the proboscis, following guides of marine mammal species identification (e.g., Reeves et al. 1992; Reeves et al. 2002; Jefferson et al. 2015).

Given the morphological similarity between the southern elephant seal and its congener species the northern elephant seal (M. angustirostris), we performed a photographic review comparing and contrasting images of these two species. This includes photos of the large males described in this work (Figs. 2a, b, and 3a), a photo of an adult male of $M$. angustirostris from San Benito Islands, Mexico (Fig. 3b; taken by the first author, Dr. D. Paéz-Rosas) and photos of a subadult and adult male M. leonina from the Valdez Peninsula, Argentina (Fig. 3c and d; courtesy of Dr. M. Drago). Since in previous sightings of elephant seals in 1998 and 2002 in the Gulf of Guayaquil (Alava and Carvajal 2005), it was not possible to describe the species with exact morphological details, the photographic records of these two individuals were also revisited.

Furthermore, the possible influence on the displacement of elephant seals towards tropical waters in Ecuador in the Eastern Pacific by negative anomalies in SST was examined. Then, the link to La Niña events, which are associated with cold conditions and primary productivity increase in the southeastern Pacific Ocean, was also assessed. Monthly anomalies of SST time series data were calculated with respect to historical climatological values (i.e. 1971-2000) in this region; SST values were obtained from the NOAA website (http://www.emc.ncep.noaa.gov/ research/cmb/sst_analysis/).

\section{Results}

The pinniped observed on October 24-28 was identified as an adult male $M$. leonina. Based on our observations and the analysis of Figs. 2a-b and 3a, this individual might correspond to a specimen of a total length of 4-5 m and weight of $2000 \mathrm{~kg}$. Conversely, the individuals sighted on December 10 and January 24 were identified as immature or subadult animals, resembling a $\sim 2$ m-length young male (Fig. 2c), and a subadult male of $\sim 4 \mathrm{~m}$ of length (Fig. 2d), respectively.

From the photographic review of images of southern elephant seals and northern elephant seals, a taxonomic identification of these animals was achieved. The major 


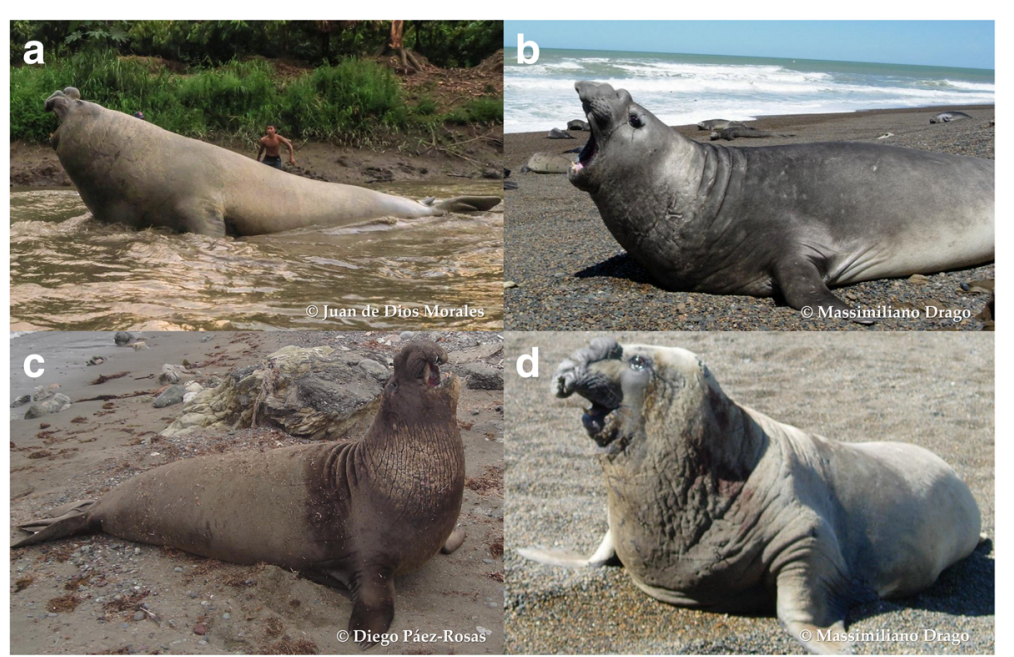

Fig. 3 External morphological comparisons illustrating the morphological differences of the adult male M. leonina observed in Milagro River, Ecuador (a) versus an adult male M. angustirostris observed in the San Benito Islands, Mexico (b). Adult (c) and subadult (d) males of M. leonina observed in the Peninsula of Valdez, Argentina, are also shown here as comparative references to corroborate the species identification. Note the shorter length of the proboscis in M. leonina adult male (a) compared to the longer proboscis of an adult male of $\mathbf{M}$. angustirostris (b), which is a key distinctive feature to differentiate $M$. leonina from $M$. angustirostris

distinctive, external morphological trait to differentiate the two species in males is the proboscis, which is shorter and smaller in M. leonina (Figs. 2a and 3a) compared to the proboscis of $M$. angustirostris, shown in Fig. 3b (Jefferson et al. 2015; Dr. L. Huckstadt, pers. comm.; Dr. F. Elorriaga-Verplancken, pers. comm., October 2017). While both species possess an enlarged nose, the proboscis in M. leonina hangs down in front of the mouth (Fig. 3a, c and d), while the proboscis in $M$. angustirostris is significantly longer, and can extend 15$25 \mathrm{~cm}$ below the lower lip (Jefferson et al. 2015). Likewise, in adult males, the neck is bulkier in relation to the head (i.e. the head to neck size ratio) in M. leonina (Fig. 3a, d) compared to that of $M$. angustirostris (Fig. 3b).

As for the juvenile $M$. leonina, the individual depicted in the Fig. 2c showed similar features to the elephant seals observed in both 1998 and 2002 in the Gulf of Guayaquil (see Fig. 1 in Alava and Carvajal 2005). Comparably, the subadult male observed at Tonsupa (Fig. 2d), showed similar features to the subadult elephant seals of the Valdez Peninsula (Fig. 3c). Both individuals (Fig. 2c, d) had undeveloped proboscises and good body conditions. Following the sighting of the animal recorded in Tonsupa, a subadult M. leonina was observed shortly after at Pianguita beach $\left(3^{\circ}\right.$ $52^{\prime} 38^{\prime \prime} \mathrm{N}, 77^{\circ} 1^{\prime} 36^{\prime \prime} \mathrm{W}$; Buenaventura, Valle del Cauca, Colombia), in late January 2018 and in the Choco region (Dr. I. Avila, pers. comm., January and April 2018).

Based on monthly anomalies of SST time series data calculated with respect to historical climatological values from 1971 to 2000 in the southeastern Pacific region, the presence of La Niña event was confirmed during October 2017, as illustrated in Fig. 4. These negative temperature anomalies (i.e. $-1.5{ }^{\circ} \mathrm{C}$ to $-0.5{ }^{\circ} \mathrm{C}$ ) and cold conditions are directly related to an increase in primary productivity levels around the area of incidence of the Humboldt Current (Ballance et al. 2006; Wang and Fiedler 2006). Therefore, we believe that the displacement of these individual seals towards tropical waters in Ecuador can be associated to a cooling La Niña event registered in the region.

\section{Discussion and conclusions}

Vagrant individuals of $M$. leonina have been reported to reach the central coast of Chile and Juan Fernandez Islands, Ecuador (Gulf of Guayaquil), Brazil's coast, southern Africa, southern Australian coast, Tasmania and New Zealand, as well as the coast of Oman (Arabian Peninsula), and the Island of Taboga (Gulf of Panama), which was the northernmost record thus far reported (Lodi and Siciliano 1989; Johnson 1990; Reeves et al. 2002; Magalhães et al. 2003; Alava and Carvajal 2005; Sepúlveda et al. 2007; Jefferson et al. 2015; Acevedo et al. 2016; Mayorga et al. 2017; Stewart and Felix 2018).

While the moulting and non-breeding seasons are critical stages obliging elephant seals to disperse to different feeding grounds, and, temporarily, haul out on land as part of their annual cycle during December-February (Campagna et al. 1993; Le Boeuf and Laws 1994), epidermal moult (i.e. sloughing and shedding of patches of fur with skin attached) was apparently observed in the subadult sighted (Fig. 2d) at Tonsupa (Esmeraldas) on January 2018, but not in the individuals recorded in October or December 2017, nor in the elephant seals recorded in December 1998 and February 2002 (Alava and Carvajal 


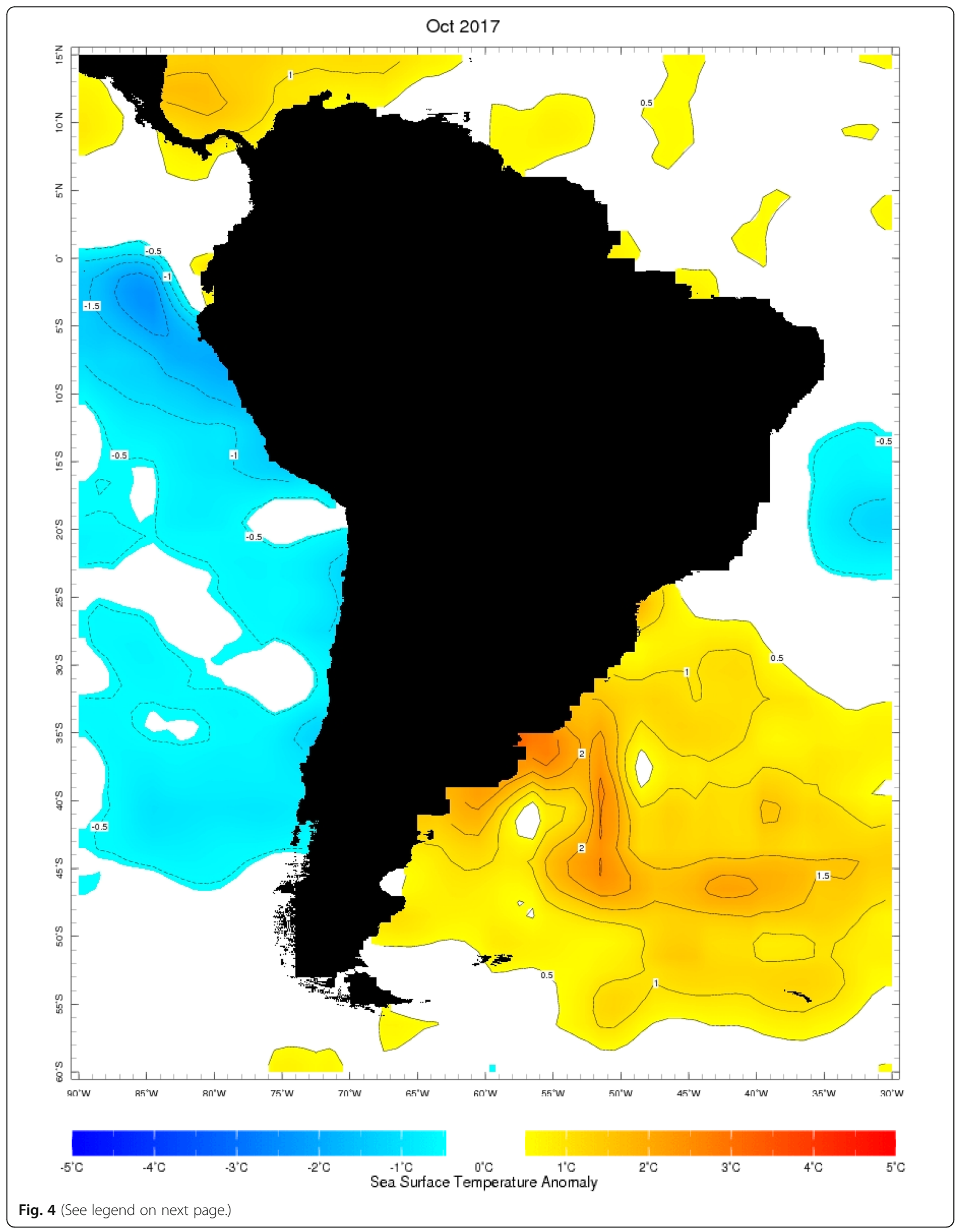


(See figure on previous page.)

Fig. 4 Monthly negative anomalies of sea surface temperature (SST) in the Southeastern Pacific Ocean during October 2017 as an example to illustrate the presence of La Nina during the occurrence for southern elephant seals from October 2017 to January 2018 in Ecuador. The blue contour tones indicate where the SST are below the historical climatological value over the baseline reference period 1971-2000. The contour for SST anomalies in the map are shown in an interval range of $0.5^{\circ} \mathrm{C}$. The SST anomaly scale is in ${ }^{\circ} \mathrm{C}$

2005). Thus, moulting cannot be considered thus far as the only physiological factor influencing the arrival of elephant seals on Ecuador's coast.

The ecological implications of these new extralimital records are important and illustrate the possible influence of climatic-oceanographic variations on the migratory patterns of M. leonina. In fact, the adult male reported here is assumed to have dispersed over a geographic range of $\sim 8000 \mathrm{~km}$ from the circumpolar/sub-Antarctic region in the Southern Ocean to tropical freshwater systems in the Gulf of Guayaquil, Ecuador. Because of the good body condition (i.e. emaciation or dehydration was not observed) of the observed adult male and juveniles, and the similarity in the sighting locations where subadult individuals were reported in 1998 and 2002 (during periods when the La Niña event also took place (Alava and Carvajal 2005), this work highlights the importance of La Niña as a driving environmental/natural force influencing the distribution and migratory behavior of this species.

This cold event is likely to have influenced or stimulated these elephant seals to pursue the cool, nutrient rich mass of water along the South American Pacific coast (Fig. 4), and thus extending their foraging trip outside the established geographic range, possibly explaining their arrival to the rivers of the Ecuadorian coast as previously proposed (Alava and Carvajal 2005). Top predators from Southern Ocean and Antarctic, including pinnipeds (i.e. southern elephant seals, M. leonina, crabeater seals, Lobodon carcinophaga, and Weddell seals, Leptonychotes weddelli) from a changing Southern Ocean and Antarctic, forage in regions where physical climatic forcing and specific oceanographic features are responsible for enhanced and increased availability of prey (Costa et al. 2010). In this context, we further postulate that the presence of sub-Antarctic pinnipeds such as southern elephant seals outside their habitual feeding or reproduction grounds would be associated with cooling periods such as La Niña.

These observations emphasize the need to strengthen collaboration and cooperation with other research groups not only at the local or regional level, but along the Pacific coast of South America and Antarctica with the aim to develop and maintain a monitoring and research program. These monitoring approaches can include satellite tracking and telemetry deployed in pinnipeds to be used as oceanographic sentinels to understand oceanographic data and key features of the southeastern Pacific, where traditional scientific oceanographic cruise and shipboard platform are limited or absent (Costa et al. 2010). This initiative will also help to assess and track distributional and behavioral patterns of pinnipeds throughout South America, mainly when there are years with anomalous oceanographic conditions that may affect the distribution, regional movements and migration of vagrant species.

\section{Abbreviations}

ENSO: El Niño Southern Oscillation; SST: Sea surface temperature

\section{Acknowledgments}

We thank the Ministry of the Environment of Ecuador for providing us with the information about the sightings and the state of the animal. Finally, we thank Dr. Leonardo Zurita and MSc. Daniela Alarcón-Ruales for help in the preparation of Fig. 1, as well as Dr. Fernando ElorriagaVerplancken, Dr. Luis Huckstadt, Dr. Massimiliano Drago and Dr. Isabel Ávila for their valuable advice for the identification of the species, the facilitation of the photographs and comments during the planning of this manuscript. We are indebt with Dr. Victoria Otton for proof reading and providing edits and insights to improve this manuscript.

\section{Funding}

The University of British Columbia (UBC, Canada), the Universidad San Francisco de Quito (USFQ-Ecuador) and Fundación Ecuatoriana para el Estudio de Mamíferos Marinos (FEMM) provided logistical and financial support during the planning and preparation of this work.

\section{Authors' contributions}

DP-R and MR-L drafted the manuscript with key contributions from JJA and $\mathrm{RC}$. JO organized logistical field support and monitoring efforts to identify and document the presence of the species. JdDM participated in the monitoring and took original photos for species identification.

All authors read and approved the final manuscript.

Ethics approval and consent to participate

Not applicable.

\section{Competing interests}

The authors declare that they have no competing interests.

\section{Publisher's Note}

Springer Nature remains neutral with regard to jurisdictional claims in published maps and institutional affiliations.

\footnotetext{
Author details

${ }^{1}$ Universidad San Francisco de Quito and Galapagos Science Center, Islas Galápagos, San Cristóbal, Ecuador. ²Dirección Parque Nacional Galápagos, Unidad Técnica Operativa San Cristóbal, Islas Galápagos, San Cristóbal, Ecuador. ${ }^{3}$ Centro Interdisciplinario de Ciencias Marinas, Instituto Politécnico Nacional (CICIMAR-IPN), La Paz, Baja California Sur, Mexico. ${ }^{4}$ Dirección Provincial de Ambiente del Guayas, Unidad de Patrimonio Natural, Ministerio de Ambiente del Ecuador (MAE), Guayaquil, Ecuador. ${ }^{5}$ Wild GYE Initiative, Investigador-Fotógrafo independiente, Guayaquil, Ecuador. ${ }^{6}$ Conservation International-Ecuador, Guayaquil, Ecuador. ${ }^{7}$ Fundación Ecuatoriana para el Estudio de Mamíferos Marinos (FEMM), Guayaquil, Ecuador. ${ }^{8}$ Institute for the Oceans and Fisheries, University of British Columbia, Vancouver, BC, Canada.
} 
Received: 11 December 2017 Accepted: 11 April 2018

Published online: 20 June 2018

\section{References}

Acevedo J, Aguayo-Lobo A, Brito JL, Torres D, Cáceres B, Vila A, Cardeña M, Acuña P. Review of the current distribution of southern elephant seals in the eastern South Pacific. New Zeal J Mar Fresh Res. 2016;50(2):240-58.

Alava JJ, Aurioles-Gamboa D. Introduction to tropical and subtropical pinnipeds. In: Alava JJ, editor. Tropical pinnipeds: bio-ecology, threats and conservation. Boca Raton: CRC Press and Taylor \& Francis Group; 2017. p. 1-11.

Alava JJ, Carvajal R. First records of elephant seals on the Guayaquil gulf, Ecuador: on the occurrence of either a Mirounga leonina or M. angustirostris. Lat Am J Aquat Mamm. 2005:4(2):195-8.

Alava JJ, Salazar S. Status and conservation of Otariids in Ecuador and the Galapagos Islands. In: Trites AW, Atkinson SK, DeMaster DP, Fritz LW, Gelatt TS, Rea LD, Wynne KM, editors. Sea lions of the world. Fairbanks: Alaska Sea Grant College Program, University of Alaska; 2006. p. 495-519.

Avila I, Alava JJ, Galvis C. Fur seal (Arctocephalus philippii) in the pacific coast of Colombia: a new extralimital record. Mastozool Neotrop. 2015;21:109-14.

Baldi R, Campagna C, Pedraza S, Le Boeuf B. Social effects of space availability on the breeding behaviour of elephant seal in Patagonia. Anim Behav. 1996;51:717-24

Ballance $L$, Pitman R, Fiedler P. Oceanographic influences on seabirds and cetaceans of the eastern tropical pacific: a review. Prog Oceanogr. 2006;69:360-90.

Campagna C, Lewis M, Baldi R. Breeding biology of southern elephant seals in Patagonia. Mar Mamm Sci. 1993;9:34-47.

Campagna C, Piola AR, Marin MR, Lewis MN, Fernandez T. Southern elephant seal trajectories, fronts and eddies in the Brazil/Malvinas Confluence. Deep Sea Res. I 2006:53:1907-24.

Costa DP, Huckstadt LA, Crocker DE, McDonald BI, Goebel ME, Fedak MA. Approaches to studying climatic change and its role on the habitat selection of Antarctic pinnipeds. Integr Comp Biol. 2010;50(6):1018-30. https://doi.org/ 10.1093/icb/icq054

Deméré T, Berta A, Adam P. Pinnipedimorph evolutionary biogeography. Bull Am Mus Nat Hist. 2003;279:32-76.

Elorriaga-Verplancken FR, Sierra-Rodríguez GE, Rosales-Nanduca H, AcevedoWhitehouse K, Sandoval-Sierra J. Impact of the 2015 El Niño-Southern Oscillation on the Abundance and Foraging Habits of Guadalupe Fur Seals and California Sea Lions from the San Benito Archipelago, Mexico. PLoS One. 2016;11(5):e0155034. pmid:27171473.

Fabiani A, Hoelzel AR, Galimberti F, Muelbert MMC. Long range paternal gene flow in the southern elephant seal. Science. 2003;299:676.

Hindell MA, McMahon CR. Long distance movement of a southern elephant seal (Mirounga leonina) from Macquarie Island Peter Peter $1 \varnothing Y$. Mar Mamm Sci. 2000;16:504-7. https://doi.org/10.1111/j.1748-7692.2000.tb00944.x

Hoelzel A, Campagna C, Arnbom T. Genetic and morphometric differentiation between island and mainland southern elephant seal populations. Proc $\mathrm{R}$ Soc Lond B Biol Sci. 2001;268:325-32

Jefferson TA, Webber MA, Pitman RL. Marine mammals of the world: a comprehensive guide to their identification. 2nd ed. San Diego: Elsevier Inc. Academic Press; 2015.

Johnson D. A southern elephant seal (Mirounga leonina) in the northern hemisphere (Sultanate of Oman). Mar Mamm Sci. 1990;12:242-3.

Kessler W. The circulation of the eastern tropical Pacific: a review. Prog Oceanogr. 2006;69:181-217

Kirkman SP, Bester MN, Hofmeyr GJ, Jonker FC, Pistorius PA, Owen R, Strydom N. Variation in the timing of the breeding haulout of female southern elephant seals at Marion Island. Aust J Zool. 2004;52(4):379-88.

Kirkman SP, Bester MN, Pistorius PA, Hofmeyr GJ, Jonker FC, Owen R, Strydom N. Variation in the timing of moult in southern elephant seals at Marion Island. S Afr J Wildl Res. 2003;33(2):79-84

Kirkman SP, Bester MN, Pistorius PA, Hofmeyr GJ, Owen R, Mecenero S. Participation in the winter haulout by southern elephant seals (Mirounga leonina). Antarct Sci. 2001:4:380-4.

Le Boeuf B. Male-male competition and reproductive success in elephant seals. Am Zool. 1974:14:163-76.

Le Boeuf B, Laws R. Elephant Seals: an introduction to the genus. In: Le Boeuf B, Laws R, editors. Elephant Seals: population ecology, behavior and physiology. Berkeley: University of California Press; 1994. p. 1-26.
Lewis M, Campagna C. Atlas de Sensibilidad Ambiental de la Costa y el Mar Argentino. Centro Nacional Patagónico (CONICET): Argentina; 2005.

Lewis M, Campagna C, Marin MR, Fernandez T. Southern elephant seals north of the Antarctic Polar Front. Antarct Sci. 2006;18(2):213-21.

Lodi L, Siciliano S. A southern elephant seal in Brazil. Mar Mamm Sci. 1989:5:313.

Magalhães F, Hassel L, Venturotti C, Siciliano S. Southern elephant seals (Mirounga leonina) on the coast of Rio de Janeiro state, Brazil. Lat Am J Aquat Mamm. 2003;2:55-6.

Mayorga LFSP, Bhering RCC, Hurtado R, Vanstreels RET. Recurrent sightings of a southern elephant seal (Mirounga leonina) on the southeast coast of Brazil 2012 - 2017. Lat Am J Aquat Mamm. 2017;12(1-2):53-8.

Mcmahon C, Bester M, Burton H, Hindell M, Bradshaw C. Population status, trends and a reexamination of the hypotheses explaining the recent declines of the southern elephant seal Mirounga leonina. Mammal Rev. 2005;35:82-100.

Modig A. Effects of body size on male reproductive behaviour in the southern elephant seal. Anim Behav. 1996;51:1295-306.

Páez-Rosas D, Valdovinos L, Elorriaga-Verplancken F. Northernmost record of the Galapagos fur seal (Arctocephalus galapagoensis): a consequence of anomalous warm conditions around the Galapagos archipelago. Aquat Mamm. 2017:43(6):627-32.

Quintana-Rizzo E, Garcia L, López RJ, Tobar-Hurtado S, López-Roulet A. First record of a Galapagos fur seal (Arctocephalus galapagoensis) in Guatemala. Mar Biodivers Rec. 2017;10(1):24. https://doi.org/10.1186/s41200-017-0126-x

Reeves R, Stewart B, Clapham P, Powell J. Guide to the Marine Mammals of the world. New York: National Audobon Society Press; 2002.

Reeves R, Stewart B, Leatherwood S. The Sierra Club Handbook of seals and Sirenians. San Francisco: Sierra Clubs Books; 1992.

Reisinger RR, Bester MN. Long distance breeding dispersal of a southern elephant seal. Polar Biol. 2010;33(9):1289-91.

Sepúlveda M, Pérez-Alvarez MJ, López P, Moraga R. Presence and re-sighting of Southern elephant seal, Mirounga leonina (L. 1758), on the north-central coast of Chile. Lat Am J Aquat Mamm. 2007;6(2):199-202.

Slade $\mathrm{R}$, Moritz HR, Burton H. Molecular population genetics of the southern elephant seal, Mirounga leonina. Genetics. 1998;149:1945-57.

Soto K, Trites A, Arias-Schreiber M. The effects of prey availability on pup mortality and the timing of birth of south American sea lions (Otaria flavescens) in Peru. J Zool. 2004:264:419-28.

Stewart R, Felix F. The most northerly record of a southern elephant seal (Mirounga leonina) in the Pacific Ocean at the island of Taboga, gulf of Panama, Panama. Aquat Mamm. 2018;44(1):13-8.

Trites A, Miller A, Maschner A, Alexander M, Bograd S, Calder J, Capotondi A Coyle K, Lorenzo E, Finney B, Gregr E, Grosch C, Royer T. Bottom-up forcing and the decline of Steller Sea lions (Eumetopias jubatus) in Alaska: assessing the ocean climate hypothesis. Fish Oceanogr. 2007;16(1):46-67.

Vargas D. Identificación de amenazas y propuesta de conservación para el Elefante Marino (Mirounga leonina) en la bahía Ainsworth, Tierra del Fuego, Región de Magallanes y Antártica Chilena, B.S. Thesis. Valdivia: Universidad Austral; 2012.

Vargas H, Steinfurth A. Primer registro de elefantes marinos en Galápagos. Informe técnico para la Estación Científica Charles Darwin y Parque Nacional Galápagos [First record of elephant seals in the Galápagos]. Isla Santa Cruz, Galápagos: Archivos ECCD; 2004.

Wang C, Fiedler P. ENSO variability and the eastern tropical pacific: a review. Prog Oceanogr. 2006:69:239-66.

Ready to submit your research? Choose BMC and benefit from

- fast, convenient online submission

- thorough peer review by experienced researchers in your field

- rapid publication on acceptance

- support for research data, including large and complex data types

- gold Open Access which fosters wider collaboration and increased citations

- maximum visibility for your research: over $100 \mathrm{M}$ website views per year

At BMC, research is always in progress.

Learn more biomedcentral.com/submissions 